\title{
OLD ENGLISH DERIVED ORDERS AT THE SYNTAX-INFORMATION STRUCTURE INTERFACE
}

\author{
Yana CHANKOVA \\ South-West University "Neofit Rilski”, Bulgaria \\ E-mail: yana_chankova@yahoo.com
}

\begin{abstract}
The present paper reports some findings from the author's research on a particular non-canonical order, derived by Scrambling and attested with double object constructions with one non-finite verb in The York-TorontoHelsinki Parsed Corpus of Old English Prose (2003). The account of Scrambling is launched in a Minimalist syntactic framework but invokes information-structural and semantic factors in an attempt to assess the extent to which the general linearization principles can be affected by such factors. The paper provides convergent support to the claim that Scrambling is an optional displacement operation raising internal Arguments and Adjuncts out of their source positions into phrasallyadjoined targets in the left periphery of vP. Assuming that Scrambling has an effect on the way constituent order correlates with discourse roles, the following paper argues that Scrambling in Old English occurs on the Syntax-Information Structure Interface, and, by corollary that it can be thought of as a type of information packaging syntactic device. Though syntactically optional, the studied Syntax-Information Structure interactions are semantically effective, i.e. they have a bearing on semantic interpretation and can best be described as interface interactions, whereby the scrambled modified orders are licensed based on their syntactic, information structural and semantic properties.
\end{abstract}

KEYWORDS: Scrambling; optional movement; Old English; double object constructions; internal adjunction; information packaging; Syntax-Information Structure Interface

This paper makes part of a larger project which seeks to reconcile Formal Syntax theory and Information Structure theory on the common ground of a specific displacement operation, i.e. Scrambling. Among the tenets of Formal Syntactic theories can be mentioned: reductionism in analysis and representation; minimalism in the number and types of primitives; precedence of formal syntactic analysis over semantic/pragmatic/ discourse explanations (as defined in Croft, 1999, p. 90). Along the above lines, the present analysis adopts a movement approach to Scrambling phenomena ${ }^{1}$ and holds that Scrambling applies optionally to raise internal Arguments and Adjuncts into left-peripheralphrasally-adjoined targets but is prohibited by Conservation of C-Command (Wallenberg, 2009, p. 132) from moving constituents across c-commanding functional heads ${ }^{2}$. But as Chomsky, himself, points out: "Notice that we are sweeping under the rug questions of considerable significance, notably questions about what in the earliest EST framework were called 'surface effects' on interpretation. These are manifold, involving topic-focus and theme-rheme structures, figure-ground properties, effects of adjacency and linearity, and many others" (Chomsky, 1995, p. 220). The given-before-newinformation packaging strategy is the default option with base-generated orders (V-IO(Dat)-DO(Acc) orders under the present study) but as Scrambling affects the structural realization of information structural categories, the derived orders may be argued to encode different information-structural constraints. Allegedly, the Scrambling movement operation interacts with general discourse principles, it may bear upon semantic and discourse interpretation, and hence Scrambling can fairly reasonably be assigned to the phenomena realized on the Interface between Syntactic Structure and Information Structure. Furthermore, as long as Scrambling phenomena in most modern languages are concerned, Syntax-Information Structure Interface features overlap with Syntax-Prosody Interface features.

The claims made above have given rise to the proposed integrated Minimalist syntactic analysis of Scrambling, based on the following basic assumptions: i) information structure relates to syntax; ii) semantics relates to syntax; iii) prosody ${ }^{3}$ is related to information structure.

\footnotetext{
${ }^{1}$ Based on Eythórsson (1995); Vikner (1997); Thráinsson (2001); Hendrick (2003); Richards (2004); Epstein and Seely (2006); Broekhuis (2008); Wallenberg (2009); Josefsson (2010); Cheng and Corver (2013).

${ }^{2}$ Technically speaking, Scrambling is an instance of internal Adjunction and it obeys Wallenberg's Conservation of C-Command constraint: "Adjunction cannot subtract a c-command relation holding between a head and a nonhead" (Wallenberg, 2009, p. 132).

${ }^{3}$ The analysis of the prosodic patterns of sentences from prose-based historical corpora takes into account context interpretation and discourse organization and there is no denying the fact that its findings can only be used as tentative clues in determining the information-structural values of sentence constituents (cf. e.g. Stewart, 2010).
} 
It is not always the case that information structure categories are "swept under the rug" by generative grammarians and factors related to semantic and information structure become salient in the context of movement operations as triggers or conditioners. The framework comes up with both a weak and a strong version, and according to the former, topic-focus, theme-rheme, figure-ground properties are to be subsumed under the purely semantic features, visible and accessible at the interface along with PF and LF, so making part of the surface effects on interpretation (Chomsky 1995 \& 2001). The strong version describes Topic and Focus as discourse-related features encoded in the syntactic component that are active in the computation, by attracting movement of constituents to dedicated functional projections (Rizzi, 1997, 2006). Acknowledging that semantic/ informational/ discourse considerations figure prominently in conditioning word order alternations cross-linguistically, the current analysis diverges from both versions and makes the soft claim that Scrambling can be semantically/ pragmatically effective, while being optional in narrow syntax. The proposed non-feature-checkingdriven account of Scrambling argues pro the optionality of this displacement operation and by entailing that scrambled orders are derived in case scrambling movement is selected, it falls within the group of those approaches which derive word order optionality from movement optionality, however, it does not entail that Scrambling is a semantically vacuous operation.

Chomsky claims that: “... optional operations can apply only if they have an effect on outcome" (Chomsky, 2001, p. 28), meaning that without such an effect the application of optional operations is illegitimate. Under the present proposal, Scrambling has information-structural and pragmatic effects on outcome which makes information structurally motivated Scrambling a feasible application of optional internal Merge. Scrambling phenomena can actually be viewed as reflexes of a universal principle, requiring that clause constituents, encoding discourse-old information or information presupposed in discourse precede clause constituents, encoding asserted, discourse-new information. In more technical terms, if VP corresponds to the focus domain and the domain above VP roughly overlaps the topical domain, non-focussed and unstressed constituents will have to move out of the VP into the domain between VP and C, whereas focused constituents have to remain within the focal domain of the sentence (e.g. Lambrecht, 1994; Diesing, 1997; Choi, 1999; Holmberg, 1999; Sundquist, 2002). In terms of OE phrase structure, Scrambling is reported to invoke old, specific, topical, defocalized interpretations. Compare, e.g., Linson's analysis after which pre-verbal position in OE is associated with previously mentioned entities or with inferable entities (Linson, 1993, pp. 84-87) and a proposal in the same vein by Foster \& Wurff (1994) regarding Middle English clause structure. While a significant number of examples from the studied $\mathrm{OE}$ corpus substantiate the above statements, examples have also been attested on whose grounds the anti-focality claim may be challenged.

The scrambleability of objects rests with various factors, viz. pronominality, definiteness (referential type), weight, and anaphoricity (cf. e.g. Meinunger, 2000; Pintzuk \&Taylor, 2004; Putnam, 2007; Bouma \& de Hoop, 2008), whereby the main findings and conclusions can be boiled down to the following claims: pronouns scramble almost obligatorily; definite objects scramble quite freely; indefinite objects scramble only rarely; longer/ heavier objects usually remain in the unscrambled position. The scrambling behaviour of indefinite objects is presumably restricted by constraints that do not hold for definite objects. As for definite objects, their scramblehaviour is presumed to be contingent on anaphoricity (previous mention in discourse) (Meinunger, 2000; de Hoop, 2003; van Bergen and de Swart, 2009).

Relativizing the application of Scrambling to the type of moving constituents and to the type of targeted landing sites, this account is focused on $\mathrm{V}_{\text {fin }}-\mathrm{IO}(\mathrm{Dat})-\mathrm{V}_{\text {non-fin }}-\mathrm{DO}$ (Acc) orders in $\mathrm{OE}$ constructions involving trivalent verbs of the give-class, characterized by the Theta grid < Agent, Benefactive/ Recipient, Theme>. Data have been collected from The York-Toronto-Helsinki Parsed Corpus of Old English Prose (Taylor, Warner, Pintzuk, Beths, 2003). The proposed analysis considers issues related to the syntactic status of ex-situ indirect objects and such, related to their informational/ discourse, semantic and prosodic properties (based on papers in Everaert and van Riemsdijk (2005); Kemenade and Los (2006); Barðdal and Chelliah (2009); Hinterhölzl and Petrova (2009); MeurmanSolin, López-Couso, and Los (2012); Nevalainen and Traugott (2012); Bech and Eide (2014); Bowern and Evans (2014)). 
If $\mathrm{V}-\mathrm{IO}(\mathrm{Dat})-\mathrm{DO}(\mathrm{Acc})^{4}$ corresponds to the underlying order in OE (Croft, 1990); Koopman (1993), Scrambling of the indirect object into the left periphery of vP will result in the following patterned variation in clauses with one non-finite verb, cf.:

1) $\quad .$. and heton him sendan maran fultum. (Chr 449)

... and bade to-them send more help

'... and they bade them send more help.'

Cf:: Se cyning het hie feohtan ongean Peohtas; and hie swa dydon, and sige hæfdon swa hwær swa hie comon. Hie pa sendon to Angle and heton him sendan maran fultum. Pa sendon hie him maran fultum. (ChrA 449)

'The king commanded them (Hengest and Horsa) to fight against the Picts; and they did so, and had victory wherever they came. Then they sent to the Angles and bade them send more help. They then sent to them more help.'

2)

$$
\begin{aligned}
& \ldots \text { et wolde him oðflitan } \\
& \ldots \text { and wanted from-him obtain by litigation tond. } \\
& \text { '... and wanted to obtain that land from him by litigation.' }
\end{aligned}
$$

Cf.: Leof ic ðe cyðe hu hit wæs ymb ðæt lond æt Funtial ða fif hida ðe Æðelm Higa ymb spycð. Đa Helmstan ða undæde gedyde ðæt he Æðeredes belt forstæl, ða ongon Higa him specan sona on mid oðran onspecendan et wolde him oðflitan ðæt lond. (ChartTh 169,23)

'Sir, I will make known to you how it was concerning that land at Funtial of five hides about which Æthelm Higa has a suit. When Helmstan committed the crime of stealing Æthered's belt then Higa along with other claimants began to make a claim against him, and wanted to get that land from him by litigation'.

3) 7 forpam se cyng nolde him agifan pæt and because the king not-would to-him restore that pe he on Normandige uppon him genumen hæfde. ${ }^{5}$ which he in Normandy against him taken had 'And since the king would not restore to him that which he had taken away from him in Normandy.'

Cf.: Đa her æfter onforan længtene wæs se cyng æt Norðhamtune. 7 se eorl Rotbert his broðer of Normandig pyder to him com. 7 forpam se cyng nolde him agifan pæt pe he on Normandige uppon him genumen hæfde. hi mid unsehte tohwurfon. 7 se eorl ferde ofer se sona eft ongean. (ChrA 1106)

'After this and before Lent the king was at Northampton. And his brother earl Robert of Normandy came to him there. And because the king would not restore to him that which he had won from him in Normandy, they separated in enmity. And the earl soon went again over sea.'

4) Se mæsse preost sceal mannum bodian pone sopan geleafan. (ÆlfWulf 175) the mass-priest must to-people preach the true belief

'The mass-priest must preach the true faith to the people.'

Cf.: Se mæsse preost sceal mannum bodian pone sopan geleafan. 7 hym lárspel secgan. 7 pa seocan geneosian. 7 cild fullian. swa rape swa man rapost mæge hi geradian to fulluhte; Gif se seoca man gyrnað pæt man hine smyrige. hé dó ponne anddetnysse ǽr pære smyrunge. (ÆlfWulf 175)

'The mass-priest must preach the true faith to the people and tell them homilies, and visit the sick, and baptize children, as soon as they can most quickly be prepared for baptism. If the sick man desires that, the priest must anoint him. He then should make a confession before being anointed.'

\footnotetext{
${ }^{4}$ In terms of standard Minimalist assumptions, the unmarked V-IO(Dat)-DO(Acc) order is straightforwardly accounted for, viz. the indirect object is base-generated in spec-VP and the direct object - in compl-V' (Chomsky, 1995).

${ }^{5}$ Borrowed from Wooing Lord (Tit D.18): Old English Homilies, ser. 1, ed. R. Morris, part 2, EETS 34 (1868; reprint 1988). pp. $269-287$ at:

http://quod.lib.umich.edu/cgi/m/mec/hyp-idx?type=id\&id=hyp.832.19981211T105002, retrieved on 17.03.2020.
} 
5)

Ond sé pe wille Drihtne bringan gecwéme lácfæsten, (BlH 34,18)

And he who wants to-lord bring pleasing offering of fast

'And he who wants to give to the Lord the pleasing offering of fast,'

Cf.: Ne gelýfe pæs nǽnig mon pæt him ne genihtsumige pæt fasten tó écere hǽlo, búton hé mid óprum gódum hit geéce. Ond sé pe wille Drihtne bringan gecwéme lácfæsten, ponne sceal hé pæt mid ælmessan ond mid mildheortum weorcum fullian. (BlH 37,18)

'Let no one believe that such fasting may suffice him for eternal salvation, unless he by other good deeds support it. And he who desires to give to the Lord the pleasing sacrifice of fast then shall he perfect that with alms and works of mercy.'

6)

$$
\begin{array}{llccc}
\begin{array}{l}
\text { Nyle } \\
\text { not-will }
\end{array} \text { he } & \begin{array}{c}
\text { ængum anum } \\
\text { to-any one }
\end{array} & \begin{array}{c}
\text { ealle } \\
\text { all }
\end{array} & \begin{array}{c}
\text { gesyllan } \\
\text { give }
\end{array} & \begin{array}{c}
\text { gæstes snyttru, (Cri 685-6) } \\
\text { of-spirit wisdom }
\end{array}
\end{array}
$$

'He will not give to anyone alone all the wisdom of the spirit,'

Cf.: Swa se waldend us,

godbearn on grundum, his giefe bryttað.

Nyle he ængum anum ealle gesyllan

gæstes snyttru, py læs him gielp sceppe

purh his anes cræft ofer opre forð. (Cri 683-7)
'So the Sovereign dispenses

his gifts to us on earth, the God-Child.

He does not wish to give all his wisdom

of spirit to any one man, lest pride over others should harm him due to his unique talent.'

But cf. $\mathrm{V}_{\text {fin }}-\mathrm{PO}$ (Dat)- $\mathrm{V}_{\text {non-fin }}-\mathrm{DO}(\mathrm{Acc})$ in:

Ic wille mid flóde acwellan
I will with flood destroy

cynna gehwilc cucra wuhta. (Gen 1297) 'I will destroy every kind of creatures alive with a flood.'

The example in 1) is canonically identified: the pronominal indirect object him moves leftwards to a position preceding the non-finite verb sendan and following the finite verb heton while the indefinite direct object maran fultum remains in its base position following sendan. In technical terms, the pronoun him must have surfaced in a position at the left edge of vP and the quantifier phrase maran fultum must have stayed in compl-VP. The light and unstressed pronoun him has evacuated out of its source position and information focus occurs solely on the quantified direct object maran fultum. The QP maran fultum which occupies the default focus domain of the last cited clause is a repeat of the earlier focussed occurrence of maran fultum and is marked by second-occurrence focus, thus adding to the information focus effect.

In 2) the ex-situ indirect object is expressed by a pronoun - him, but here the unmoved direct object is definite, expressed by the determiner phrase ðat lond. The unfocussed pronoun him scrambles to a left-adjoined position and the assumably focussed DP ðat lond remains within the default sentence focus position. Definite and specific objects usually scramble but ðat lond remains within the focal area by being marked by end-focus. This one, in addition, receives second-occurrence focus as it reiterates the DP ðat lond which makes part of the PP ymb ðat lond to be found in the first subordinate clause of the initial sentence and thus becomes doubly prominent.

In the reason-clause in 3), both objects are pronominal and light, and, quite as expected, the unfocussed anaphoric indirect object him moves leftwards but the direct object pronoun pat stays in its underlying position and remains contiguous to the following relative clause pe he on Normandige uppon him genumen hafde that identifies its reference. Object pronouns do obligatorily scramble but there is still the possibility for a pronoun to remain in its base-generated position, if it carries focus stress. Clitic negation (here spelled out as nolde) originates in the head of NegP marking clauses as negative in force and in clauses without optional constituents negative-contrastive focus has the widest scope, viz. it can impact the whole proposition or else it can occur on any clausal constituent. The latter making a case for 3), negative-contrastive focus may be assumed for the direct object pronoun paet and a functionally heavy paet will stay in situ. Contrastive focus differs from regular informational focus in that it may not carry really 'new' information and is not incompatible with an anaphoric pronoun.

In 4) the indefinite indirect object mannum, rendered by a bare nominal, evades the restrictions on Scrambling of indefinite noun phrases and the in-situ direct object pone sopan geleafan evades the definiteness effect. A definite DP object usually refers to shared or pre-supposed information and will not stay in its base position, especially when an indefinite object is preposed but contrastive focus can furnish a reason for pone sopan geleafan to escape the definiteness effect. One suggested explanation 
for the movement of mannum is that it scrambles under a particular interpretation, viz. a generic reading. Verbs are rarely focussed in OE prose and a look at the context reveals an intriguing fact: in the following three elliptical clauses all internal Arguments have evacuated out of the default sentence focus area, so that end-focus occurs on the respective verbs secgan, geneosian and fullian.

In 5) both objects are indefinite, the ex-situ object being rendered by the bare nominal Drihtne and the in-situ object - by the heavier adjective phrase gecwéme lácfoesten. The indefinite direct object gecwéme lácfaesten remains within the default focus domain by receiving second-occurrence focus, provided that the DP paet fasten occupies the subject position in the subordinate pat-clause of the initial sentence. If we consider 5) in the light of Diesing (1997)'s claim concerning Yiddish pre-verbal objects, a special contrastive interpretation for the ex-situ object Drihtne can be proposed.

6) actually represents a variety of the $\mathrm{V}_{\text {fin }}-\mathrm{IO}$ (Dat)- $\mathrm{V}_{\text {non-fin }}-\mathrm{DO}$ (Acc) pattern, given that the head of the QP direct object - the quantifier ealle, is scrambled along with the indirect object QP angum anum, while the complement part of the direct object gaestes snyttru remains in situ. Both objects are indefinite, realized by quantifier phrases, and for the time being I assume a special contrastive interpretation for the elements attested in the middle field.

The example in 7), wherein the prepositional dative object mid flóde is base generated in complVP and the direct object cynna gehwilc cucra wuhta - in spec-VP, is intended to show that OE Scrambling can target prepositional phrases. The preposition mid is pied-piped with the noun flóde as the PP mid flóde moves out of the default sentence focus area to receive contrastive focus in its newlyadjoined position, while the direct object cynna gehwilc cucra wuhta, comprising three nominal constituents in the Gen case - cynna ... cucra wuhta, in addition to the definite pronoun gehwilc in the Acc case remains in situ due to considerations of length. A fact about 7) which is pertinent to the following syntactic analysis is that the PP midflóde did not move for the purpose of case checking, viz. at Merge the preposition mid has checked the structural Dative case feature on its bare nominal complement flóde, and the PP mid flóde checks the thematic (Dative) case on the verb acwellan in another instance of Merge. As a result, the PP mid flóde becomes caseless before being targeted by the Scrambling rule. It has been mentioned above that this account diverges from both the weak and the strong version of semantic/ discourse/ informational analyses and it needs to be mentioned that it also departs from case-feature-driven analyses under which movement is triggered by the need for the internal Arguments to have their case-features checked (e.g. Collins \& Thráinsson, 1996; Roberts, 1997; Haeberli, 1999; van der Wurff, 1999). My response to the above studies features an analysis, whereby Scrambling applies regardless of case checking/ licensing requirements, and lines up with later versions of Minimalism which posit that feature valuation can be established under c-command (Chomsky, 2001).

Let us now turn to considering the schematic representation of 6) that is herein derived as a focusing construction which is so interpreted by reason of having a silent $\mathrm{OpF}$ (or a null discourse related operator) in spec-CP (Scheme 1.).

8) In 8) the quantifier ealle has been extracted from the QP ealle gastes snyttru, thus turning the QP into a non-constituent string, and moved into the left periphery to adjoin to vP (much in tune with Beghelli \& Stowell (1997) and Fox \& Nissenbaum (1999) where the target of Quantifier Raising is identified as an adjunction position in the domain between $\mathrm{vP}$ and TP) and this induces a contrastive or focused reading for ealle. It has been argued in Chankova (2016) that OE has differential object marking, meaning every direct object in OE bears structural accusative case, which in the case of ealle is realized by overt morphology. The Acc Case feature on ealle snyttru is checked by little $\mathrm{v}$ by virtue of its accusative Case feature. The base position of ealle snyttru lies within the checking domain of little $\mathrm{v}$, so it need not move out of it, either overtly or covertly, and unsurprisingly the nominal element gæstes snyttru stays in situ. If structural case were the driving force behind Scrambling of the direct object, gaestes snyttru must have been lowered, once case-checking obtains. Next, the indirect object QP angum anum moves out of spec-VP to adjoin above the quantifier ealle in its target position. When angum anum has merged in spec-VP, the verb gesyllan has assigned angum anum the Theta-role Recipient and has also checked its Dat case-feature. With its inherent dative case being checked in situ, angum anum might well have stayed in its underlying position but for information structural concerns. 
In 8), however, both the quantifier ealle and the QP angum anum surface in target positions to the left of gesyllan $k+v$ and thus violate Conservation of C-Command. It seems that the functional head little $v$ does not count as a barrier to Scrambling and the odds are high that this is due to some property of little $v$, on whose account Scrambling is not rendered illicit. There exist diagnostic criteria to distinguish

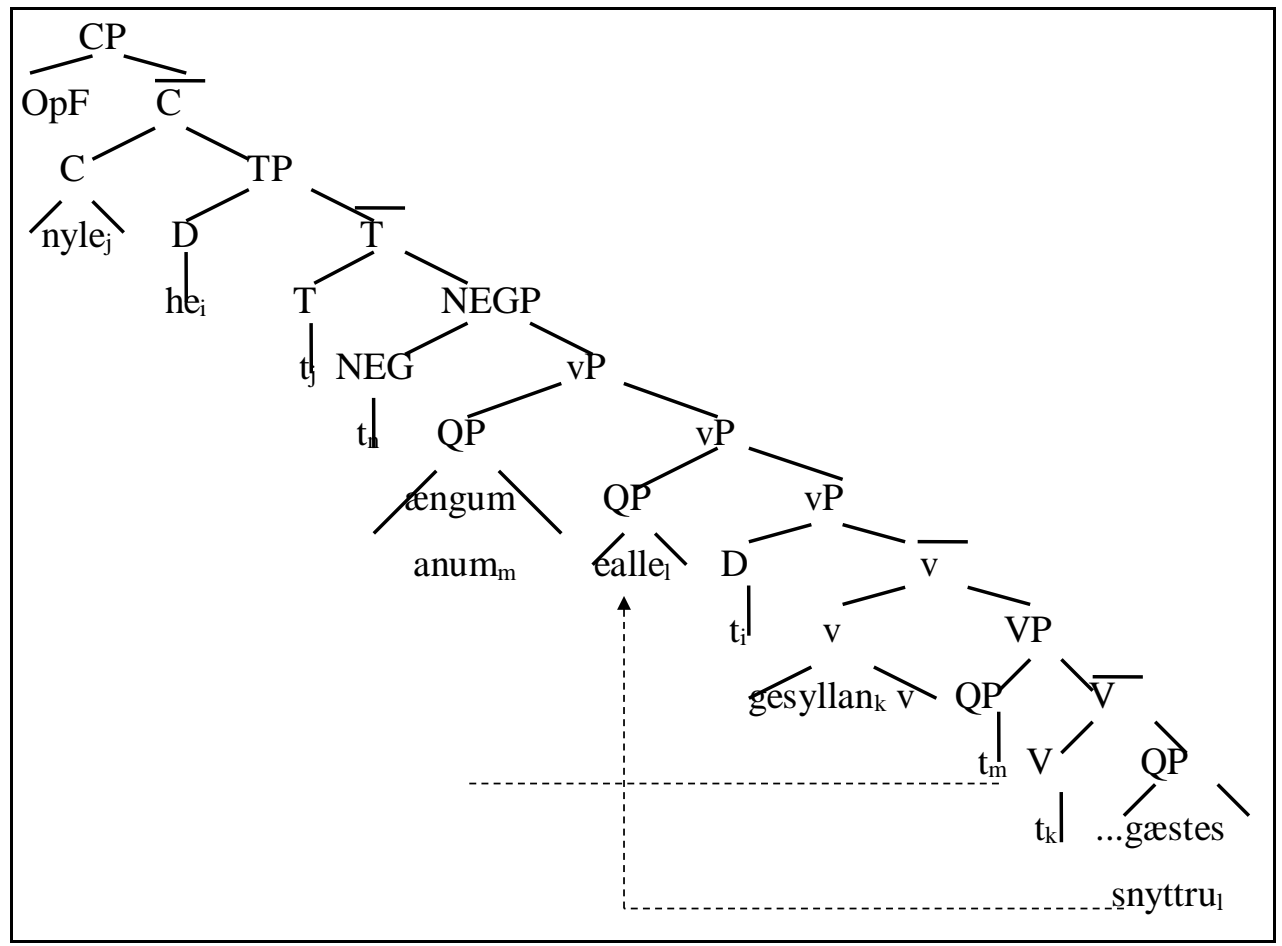

Scheme 1.

functional from lexical categories, e.g. within the framework of late Minimalism, Chomsky (2001) states that Move is solely triggered by the EPP features on the functional heads $\mathrm{C}, \mathrm{T}$ and little $\mathrm{v}$. Haegeman (2006), however, draws a distinction between lexical and functional categories, based on their ability for Theta-role assignment and argues that functional categories are unable to assign Thetaroles. Back to 8), the head little $v$ assigns the Theta-role Agent to the subject he in spec-vP, and it allows for leftward movement of ealle and angum anum crossing it, hence, in view of Haegeman's analysis, it is only plausible to describe little $v$ as a hybrid head, conflating properties of both functional and lexical heads.

In a recap, the proposed analysis of Scrambling has argued that this displacement operation is not triggered by attracting formal features and does not take constituents to designated target positions, and in this sense Scrambling is optional. It is the syntactic status of Scrambling as a case of internal adjunction that defines its optional character but at the same time Scrambling is a constrained operation that applies locally to a certain c-command domain, i.e. Scrambling movement targets a left-peripheral adjunction position in the domain between vP and TP. The application of Scrambling as an optional operation is licit in the sense of Chomsky (2001) since disrupting the base-generated order of constituents is construed in connection with information-structural/ semantic properties, hence, an information structural effect on outcome is achieved. The studied interactions of word order, information structure, semantic interpretation and prosody have been explained as interface interactions that license scrambled orders on the basis of their syntactic, information structural, semantic and prosodic properties. As syntax interfaces with the above syntax-external systems, they modify word order options but do not affect syntax. Base-generated word order and Scrambling of pronouns favour unmarked interpretation, Scrambling definite phases is a less marked option than Scrambling indefinite phases, Scrambling focussed phases is more marked than Scrambling unfocussed phrases.

Within the limited perspective of an analysis focused on $\mathrm{V}_{\text {fin }}-\mathrm{IO}\left(\right.$ Dat) $-\mathrm{V}_{\text {non-fin }}-\mathrm{DO}$ (Acc) orders in OE, the following properties of Scrambling have been highlighted: 
i) OE Scrambling targets XPs (case-marked DPs and caseless PPs included) but nonconstituents can also be scrambled.

ii) The source position is case-marked and the target position is non-case-marked with DP Arguments, PPs (Adjuncts) and non-constituents.

iii) OE Scrambling evokes a variety of information-structural/ semantic effects: some ex-situ XPs/ non-constituents may be construed in terms of contrastive, non-presupposed, focused interpretations.

iv) Weight and definiteness govern the linearization of constituents in OE scrambled structures to a lesser extent as compared to semantic and information-structural factors.

v) As syntactic structure interfaces with information structure, this yields a new SyntaxInformation Structure configuration: Scrambling has information-structural effects on outcome.

vi) The type of word order variation studied can be best described as the result of a complex interaction between syntactic, information-structural, semantic and prosodic factors.

\section{REFERENCES:}

Barðdal, J., S. Chelliah (2009)

Bech, K., K. Eide (2014)

Beghelli, F., T. Stowell (1997)

van Bergen, G., P. de Swart (2009)

Bouma, G., H. de Hoop (2008)

Bowern, C., B. Evans (2014)

Broekhuis, H. (2008)

Chankova, Y. (2016)

Cheng, L., N. Corver (2013)

Choi, H. W. (1999)

Chomsky, N. (1995)

Chomsky, N. (2001)

Collins, C., H. Thráinsson (1996)

Croft, W. (1990)

Croft, W. (1999)

Diesing, M. (1997)

Epstein, S., T.D. Seely (2006)

Everaert, M., H. van

Riemsdijk (2005)

Eythórsson, Th. (1995)

Foster, T., W. van der

Wurff (1994)

Fox, D., J. Nissenbaum (1999)

Haeberli, E. (1999)
The Role of Semantic, Pragmatic and Discourse Factors in the Development of Case. Amsterdam, Philadelphia: John Benjamins.

Information Structure and Syntactic Change in Germanic and Romance languages. Amsterdam, Philadelphia: John Benjamins.

The Syntax of Distributivity and Negation. - In: Szabolsci, A. Ways of Scohkipe Taking. Dordrecht: Kluwer, p. $71-108$.

Definiteness and Scrambling in Dutch: Where Theory Meets Practice. - In: Proceedings of the North East Linguistic Society (NELS), v. 38, p. 113 - 124.

Unscrambled Pronouns in Dutch. // Linguistic Inquiry, v. 39 (4), pp. 669 - 677.

The Routledge Handbook of Historical Linguistics. London, New York: Routledge.

Derivations and Evaluations (Object Shift in the Germanic Languages). Berlin, New York: Walter de Gruyter \& Co.

Aspects of the Theory of Scrambling. Blagoevgrad: South-West University Press.

Diagnosing Syntax. Oxford: Oxford University Press.

Optimizing Structure in Context: Scrambling and Information Structure. Stanford, California: CSLI Publications.

The Minimalist Program. Cambridge, MA: Massachusetts Institute of Technology Press.

Derivation by Phase. - In: Kenstowicz, M. Ken Hale: A Life in Language. Cambridge, MA: Massachusetts Institute of Technology Press, p. 1-52.

VP-Internal Structure and Object Shift in Icelandic. // Linguistic Inquiry, v. 27(3), p. $391-444$.

Typology and Universals. Cambridge: Cambridge University Press.

What (Some) Functionalists Can Learn from (Some) Formalists. In: Darnell, M., Moravcsik, E., Noonan, M., Newmeyer, F., Wheatley, K. Functionalism and Formalism in Linguistics. General Papers. Amsterdam: John Benjamins Publishing Co, p. $87-110$.

Yiddish VP Structure and the Typology of Object Movement. // Natural Language and Linguistic Theory, v. 15(2), p. $369-427$.

Derivations in Minimalism. Cambridge: Cambridge University Press.

The Blackwell Companion to Syntax. Oxford: Blackwell.

Verbal Syntax in the Early Germanic Languages. PhD diss., Cornell University. From Syntax to Discourse: The Function of Object-Verb Order in Late Middle English. Leiden: Leiden University Press.

Extraposition and Scope: A Case for Overt QR. - In: Proceedings of the 18th West Coast Conference on Formal Linguistics, v. 18, pp. 43 - 54.

Features, Categories and the Syntax of A-Positions. Synchronic and Diachronic Variation in the Germanic Languages. PhD diss., University of Geneva. 
Haegeman, L. (2006)

Hendrick, R. (2003)

Hinterhölzl, R., Petrova (2009)

Holmberg, A. (1999)

de Hoop, H. (2003)

Josefsson, G. (2010)

van Kemenade, A., B. Los (2006)

Koopman, W. (1993)

Lambrecht, K. (1994)

Linson, B. (1993)

Meinunger, A. (2000)

Meurman-Solin, A., M. Lopez-Couso, B. Los (2012)

Nevalainen, T., E. The Oxford Handbook of the History of English. Oxford: Oxford University Traugott (2012)

Pintzuk, S., A. Taylor (2004)

Putnam, M. (2007)

Richards, M. (2004)

Rizzi, L. (1997)

Rizzi, L. (2006)

Roberts, I. (1997)

Stewart, D. (2010)

Sundquist, J. (2002)

Thráinsson, H. (2001)

Vikner, S. (1997)

Wallenberg, J. (2009)

van der Wurff, W. (1999)

$<$ http://home.adm.unige.ch/ haeberli/papers.htm $>$ (08.01.2020).

Argument Fronting in English, Romance CLLD and the Left Periphery. - In: Zanuttini, R., Campos, H., Herburger, E., Portner, P. Crosslinguistic Research in Syntax and Semantics: Negation, Tense and Clausal Architecture. Washington, D.C.: Georgetown University Press, pp. $27-52$.

Minimalist Syntax. Oxford: Blackwell.

S. Information Structure and Language Change. New Approaches to Word Order Variation in Germanic. Berlin: Mouton de Gruyter.

Remarks on Holmberg's Generalization. // Studia Linguistica, v. 53(1), pp. 139.

Scrambling in Dutch: Optionality and Optimality. - In: Karimi, S. Word Order and Scrambling. Oxford: Blackwell, pp. 201-216.

Object Shift and Optionality. An Intricate Interplay between Syntax, Prosody and Information Structure. // Working Papers in Scandinavian Syntax, v. 86, pp. $1-24$.

The Handbook of the History of English. Oxford: Blackwell Publishing.

The Order of Dative and Accusative Objects in Old English and Scrambling. // Studia Anglica Posnaniensia, v. 25 - 27, pp. 109-121.

Information Structure and Sentence Form. Cambridge: Cambridge University Press.

A Pragmatics of Word Order in Old English Prose. Philadelphia: University of Pennsylvania dissertation.

Syntactic Aspects of Topic and Comment. Amsterdam: John Benjamins.

Information Structure and Syntactic Change in the History of English. Oxford: Oxford University Press.

\section{Press.}

The Loss of OV Order in the History of English. In: van Kemenade, A., Los, B. Blackwell Handbook of the History of English. Oxford: Blackwell Publishing, pp. $249-279$.

Scrambling and the Survive Principle. Amsterdam, Philadelphia: John Benjamins.

Object Shift and Scrambling in North and West Germanic: A Case Study in Symmetrical Syntax. PhD diss., University of Cambridge.

$<\underline{\text { http://uni-leipzig.de/ richards/papers_files/Marc_Richards_PhD.pdf }>}$ (05.01.2020).

The Fine Structure of the Left Periphery. In: Haegeman, L. Elements of Grammar. Dordrecht: Kluwer, pp. 281-337.

On the Form of Chains: Criterial Positions and ECP Effects. - In: Cheng, L., Corver, N. Wh-Movement: Moving on. Cambridge, MA: Massachusetts Institute of Technology Press, pp. $97-133$.

Directionality and Word Order Change in the History of English. In: van Kemenade, A., Vincent, N. Parameters of Morphosyntactic Change. Cambridge: Cambridge University Press, pp. 397 - 426.

Semantic Prosody. A Critical Evaluation. New York, London: Routledge.

Object Shift and Holmberg's Generalization in the History of Norwegian. - In: Lightfoot, D. Syntactic Effects of Morphological Change. Oxford: Oxford University Press, pp. $326-347$.

Object Shift and Scrambling. - In: Baltin, M., Collins, C. The Handbook of Contemporary Syntactic Theory. Oxford: Blackwell Publishing, pp. 148-212.

The Interpretation of Object Shift, OT and Minimalism. // Working Papers in Scandinavian Syntax, v. 60, pp. 1-24.

Antisymmetry and the Conservation of C-command: Scrambling and Phrase Structure in Synchronic and Diachronic Perspective. PhD diss., University of

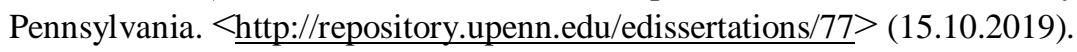

Objects and Verbs in Modern Icelandic and Fifteenth Century English: A Word Order Parallel and Its Causes. // Lingua, v. 109, p. 237-265. 